УДК 332.055.2

DOI: https://doi.org/10.37320/2415-3583/13.17

Новіков Д.В. аспірант,

Київський наиіональний університет технологій та дизайну ORCID: https://orcid.org/0000-0003-4159-993X

\title{
КОНЦЕПЦІЯ СОЦІАЛЬНОЇ ВІДПОВІДАЛЬНОСТІ БІЗНЕСУ В АГРАРНОМУ СЕКТОРІ УКРАЇНИ
}

У статті розглянуто теоретичні засади соціального відповідальності бізнесу, зокрема зосереджено увагу на дотриманні принципів відповідального введення господарської діяльності в українському аграрному секторі. Сформовано кониептуально-сучасне визначення поняття «соиіальна відповідальність агропідприємств». Проаналізовано моделі СВБ та розкрито їх переваги й недоліки. Визначено етап становлення політики СВБ в українському сільському господарстві. На прикладі найбільших латифундистів України проведено порівняльну характеристику сочіальної політики щодо фінансів та кількості заходів і проєктів. Сформовано основні напрями реалізащії СВБ українськими аграріями. Розроблено рекомендації щзодо подальшого становлення та впровадження моделей СВБ на відповідних рівнях введення господарської діяльності.

Ключові слова: сочіальна відповідальність бізнесу, сочіальна відповідальність агропідприємств, моделі СВБ, конкурентна перевага, латифундисти Украӥни, стейкхолдери.

Постановка проблеми. В епоху динамічного розвитку 1/3 світового господарства 2/3 перебувають у протилежному становищі щодо процесу впровадження принципів і механізму функціонування ринкової економіки. Розглядаючи поточний період, тобто першу половину 2020 року, маємо говорити про низку подій, які повністю є підгрунтям техніко-технологічного та політико-економічного порядку сучасного глобалізованого світу. 3 урахуванням умов, що склалися внаслідок пандемії COVID-19, світ зіткнувся з проблемами інформаційної невизначеності та дистанціювання виробничих процесів і надання послуг або повної ізоляції малого та середнього бізнесу, тому адаптивність до нових умов і вміння оптимально використовувати наявні конкурентні переваги дадуть змогу суб'єктам господарювання мінімізувати ризики щодо втрат у кількісному та якісному виразі. Згідно з теорією Адама Сміта щодо принципу «невидимої руки», суспільство у цей момент часу зовсім не виробляє спільних благ, тому його дія близька до нуля. Саме тому слід розглянути спектр соціальної політики підприємств як чинник впливу на їх конкурентоспроможність та індикатор фінансової стабільності суб'єктів господарювання. СВБ належить до менш пріоритетних напрямів діяльності, тому головним завданням постає побудова стратегії розвитку компанії з урахуванням принципів і постулатів СВБ.

Аналіз останніх досліджень і публікацій. Важливість та доцільність вивчення соціальної відповідальності бізнесу відзначаються в наукових працях багатьох іноземних і вітчизняних учених. Зокрема, М. Портер і М. Крамер у статті «Стратегія і суспільство: зв’язок між конкурентною перевагою і соціальною відповідальністю» заявили, що «найчастіше відповідь компаній на завдання в галузі СВБ є косметичною, ніж стратегічною або операційною - PR-кампанії, в центрі яких перебувають глянцеві звіти зі СВБ»[3].

Прихильники «зовнішньої» природи джерел СВБ, такі як Т. Левітт, М. Фрідман, Дж. Гелбрейт, що переважно $є$ фахівцями в галузі економіки, політології та менеджменту, наполягали на тому, що діяльність біз- несу обумовлюється суспільним договором, а відповідальність є обов'язком бізнесу перед суспільством [4].

Наслідувачі «внутрішньої» природи джерел СВБ, такі як Дж. Ладд, П. Френч, Дж. Данлі, К. Годпастер, Дж. Метьюз-мл. і М. Веласкес, що переважно є представниками філософської науки, прихильниками морально-агентської позиції, стверджували, що відповідальний підхід до справи - це виключно самостійний вибір представників бізнесу, і вони на повній підставі можуть не тільки дотримуватися встановлених суспільством правил, але й ставати творцями цих правил [4].

К. Девіс писав, що бізнес - це спільне «підприємство», яке об'єднує відповідальних громадян та групи інвесторів, менеджерів, працівників, вчених і місцеві спільноти [1].

Серед вітчизняних науковців доцільно відзначити таких, як I. Акімов [4], В. Воробей [5], Т. Смовженко [10], С. Мельник [11], П. Шевчук [14].

Мета статті полягає у визначення стану розвитку СВБ найбільших агропідприємств України та формуванні відповідних рекомендацій щодо вирішення наявних проблем.

Виклад основного матеріалу. Термін «соціальна відповідальність бізнесу» має свої витоки із середини XX ст. і стверджує, що бізнес, крім дотримання законів і виробництва якісного продукту, добровільно бере на себе додаткові зобов'язання перед суспільством, здійснює значний внесок у підвищення якості життя людей [4].

За Ф. Котлером, це поняття набуває класичних рис і визначається як «вільний вибір компанії на користь зобов'язання підвищувати добробут суспільства, реалізовуючи відповідні підходи до ведення бізнесу і виділяючи корпоративні ресурси» [2].

Згідно $з$ місією та принципами діяльності Свропейського Альянсу корпоративної соціальної відповідальності (створений у 2006 році), соціальна відповідальність визначається як концепція залучення соціальних та екологічних напрямів у діяльність бізнесу на засадах добровільності та взаємодії між усіма зацікавленими сторонами (групами впливу) [5].

3 огляду на тлумачення, які перераховані вище, соціальна відповідальність бізнесу сформована на 
добровільному виборі здійснювати господарську діяльність з урахуванням інтересів кожного зі стейкхолдерів, а також дотриманні толерантності й побудові еко-френдлі образу в суспільстві задля отримання максимального ефекту від здійснення основної діяльності.

Аграрний сектор України щодо реалізації принципів СВБ $є$ одним 3 найголовніших центрів впровадження міжнародних стандартів у сфері охорони праці, екології, використання інновацій, взаємодії з місцевими контактними групами та вжиття соціальних заходів і проведення програм для підвищення економічного рівня життя місцевого населення, адже більшість українських агропідприємств співпрацює 3 іноземними компаніями, які у договорі на здійснення певної операції (продаж зерна, техніки тощо) обов'язково мають перевірку на відповідність українського підприємства їхнім стандартам праці («Який відсоток людей з обмеженими можливостями працює на вашому підприємстві»), екології («Який рівень забруднення надходить від автомобілів, що використовує фірма»).

Також СВБ постає показником конкурентоспроможності агропідприємств, особливо зернотрейдерів, у їхній діяльності основним фактором виробництва $\epsilon$ земля, а саме орендні земельні відносини. Орендодавці $\epsilon$ цільовою аудиторією СВБ, адже, окрім встановленої орендної плати за земельну ділянку, вони також отримують низку бонусів і переваг. Отже, тут починає діяти «невидима рука» А. Сміта, адже місцева громада також має зиск від наявності декількох аграріїв. Останні влаштовують справжню конкурентну боротьбу у вжитті соціальних заходів і програм для розвитку відповідного населеного пункту, тому в Україні аграрний сек- тор є не лише галуззю, що формує ВВП, але й сферою, де бере свій початок стратегічна СВБ.

Соціальна відповідальність агропідприємств - це цільова діяльність, яка містить стратегічне підгрунтя задля реалізації правил і принципів стійкого розвитку для створення максимально можливого соціального ефекту для кожного зі стейкхолдерів.

Питання соціальної відповідальності бізнесу розглядається на глобальному та національному рівнях, тому для різних країн сформовано характерні моделі соціально відповідального бізнесу.

У сучасному світі країни з демократичним устроєм і розвиненим громадянським суспільством активно впроваджують практику соціально відповідального бізнесу (Англія, США, Німеччина, Скандинавські країни).

Основними моделями соціально відповідального бізнесу $є$ :

- Англо-американська;

- європейська;

- скандинавська;

- «бізнес відповідає за все» (рис. 1) [14].

Проблематика імплементації СВБ у філософію господарської діяльності українських підприємців полягає у відсутності фундаментального законодавчого базису, який сприятиме збільшенню соціального ефекту на добровільній основі. Ця точка зору є суміжною із західноєвропейською моделлю СВБ і, відповідно, актуалізує активізацію українського ділового середовища для створення фундаментальних постулатів взаємодії всіх представників контактних груп. Оскільки принципи ринкової економіки продукують альтернативність у масиві рішень, то концепція СВБ безпосередньо відпо-

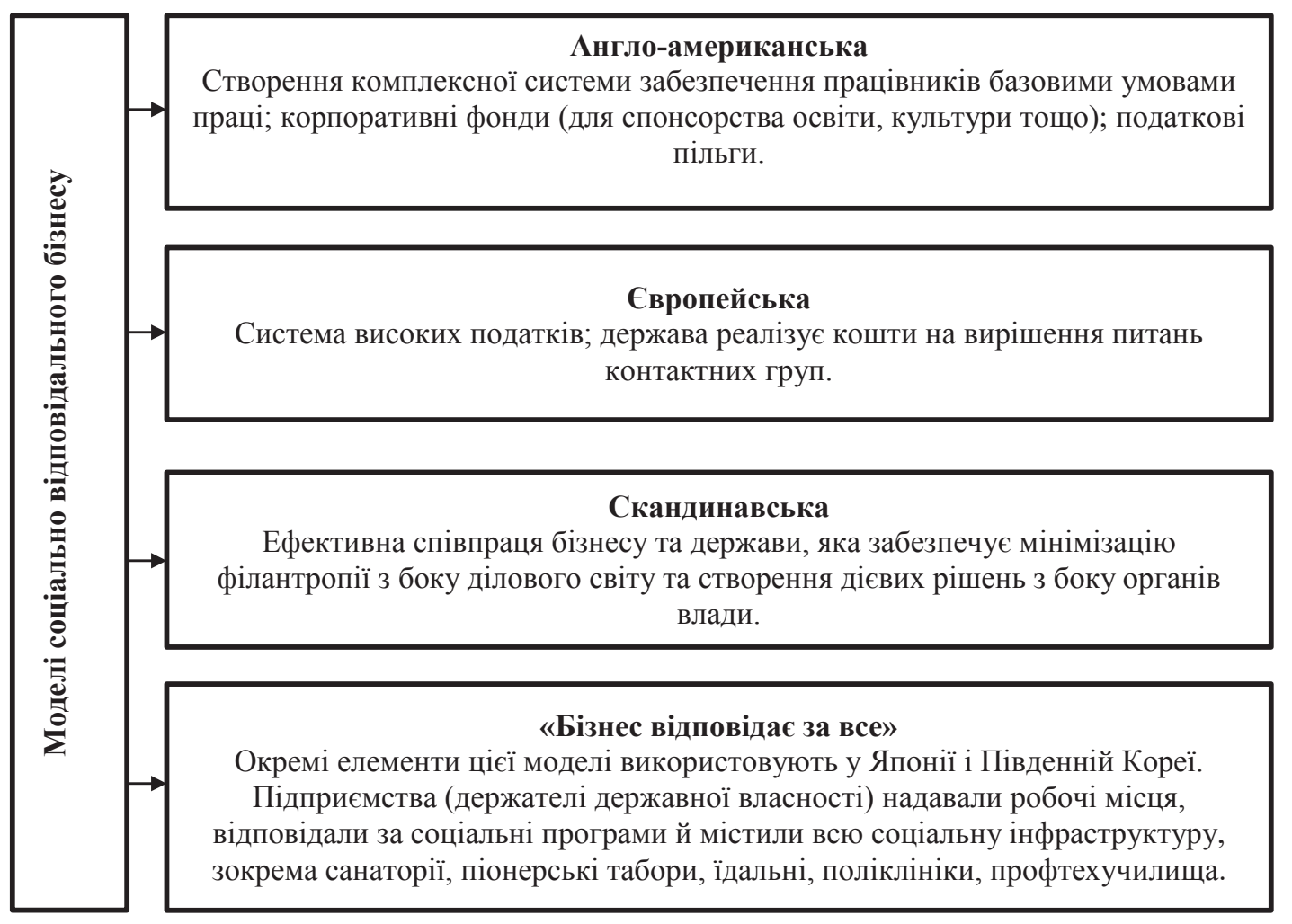

Рисунок 1 - Характеристика моделей соціально відповідального бізнесу

Джерело: сформовано автором за матеріалами джерела [14] 
відає за розширення меж діяльності підприємців задля мінімізації частки «тіньового бізнесу».

Українському варіанту СВБ притаманні такі риси:

- частково сформована концепція СВБ в Україні зовсім не відповідає наявним моделям провідних країн світу (США, Німеччина, Японія, Китай тощо);

- питання добровільності постає особливо гостро, адже СВБ має вимушений характер або здійснюється «заради піару»;

- висока вагомість особистісного контакту у формуванні програм соціальної політики як на рівні держави та регіонів, так і на рівні підприємств;

- мультиваріативність соціальної активності, сформованої на основі вирівнювання соціальної необхідності та соціального ефекту;

- наявність розбіжності у поглядах та баченні щодо пріоритетності проблем і рішень щодо населення й бізнесу.

На основі наведених моделей можна проаналізувати соціальну політику аграрних підприємств України. Відслідковуючи останні тенденції, можемо відзначити, що український бізнес набирає обертів у становленні та впровадженні принципів відповідального підприємництва. Український діловий світ в умовах євроінтеграції передбачає встановлення європейських стандартів у середньостроковій та довгостроковій перспективі. Так, на прикладі провідних аграрних підприємств можна відслідкувати переорієнтацію з базисних видів соціальної відповідальності (легітимність бізнесу, гідні умови праці, філантропія тощо) на більш стратегічні багаторівневі проєкти із залученням стейкхолдерів відповідно до їх інтересів (табл. 1).

Для деталізації поточного стану СВБ в аграрному секторі України розглянемо соціальні програми та проєкти, які реалізують представники топ-100 латифундистів. У Стародавньому Римі латифундіями (лат. "Latus" - «просторий» i "fundus" - «ферма, нерухомість») називалися великі маєтки, які спеціалізуються на експортних галузях сільського господарства, таких як вирощування зернових, виробництво оливкової олії і виноробство [9]. Серед них проаналізуємо лише чотирьох представників (табл. 1).

Згідно зі статистичними даними, найбільшу соціальну підтримку надає «КЕРНЕЛ», а саме 57 млн. грн., значно менше - «Астарта-Київ» (2,89 млн. грн.). Така різниця обумовлюється специфікою діяльності та масштабом іiі проведення [6;8].

Тенденція впровадження елементів соціальної відповідальності бізнесу поширюється також на представників середнього й малого підприємництва. Напрями реалізації майже ідентичні, адже лише відрізняються заходи та проєкти, а також масштаби й ресурси. Поки визначеної моделі українського соціального відповідального бізнесу не існує, адже потрібно пройти ще низку етапів становлення для формування ефективного шляху для здійснення соціальної політики.

Таке різноманіття та підвищена активність насамперед спричинені боротьбою за лояльність споживача (орендодавця). Саме тому соціальна відповідальність бізнесу постає вагомою складовою частиною формування конкурентоспроможної позиції підприємства. Це виявляється у:

- формуванні доброзичливого іміджу;

- створенні конкурентних умов праці;

- забезпеченні довгострокових відносин зі споживачами та клієнтами;

- зміні бачення стейкхолдерів [10].

Проте рівень соціальної відповідальності українських аграріїв та бізнесу загалом передбачає вирішення таких завдань для його підвищення:

- формування дієвого правового поля (забезпечення виконання та дотримання усіма учасниками бізнес-процесів відповідних правових норм і законів);

- впровадження стратегічного підходу до розроблення соціальних проєктів;

Таблиця 1 - Соціальна відповідальність бізнесу топ-5 латифундистів України

\begin{tabular}{|c|c|c|}
\hline Підприємство & Напрями & Проскти \\
\hline «Кернел» & $\begin{array}{l}\text { - Довкілля; } \\
\text { - умови праці; } \\
\text { - співпраця з громадами (освіта, охорона здоров'я, } \\
\text { інфраструктура та благоустрій, культура та громадські } \\
\text { ініціативи, спорт, соціальне підприємництво); } \\
\text { - відповідальність за якість продукції. }\end{array}$ & $\begin{array}{l}\text { БФ «Разом з Кернел» (2010 рік), фонд } \\
\text { займається фінансовою та матеріальною } \\
\text { підтримкою громад, «Зелений офіс», } \\
\text { «Стале землеробство», Сертифікація } \\
\text { продукції, «Здоров’я громад». }\end{array}$ \\
\hline «МХП» & $\begin{array}{l}\text { - Довкілля; } \\
\text { - біобезпека; } \\
\text { - етична лінія підтримки; } \\
\text { - умови праці; } \\
\text { - турбота про рослин, тварин; } \\
\text { - якість продукції. }\end{array}$ & $\begin{array}{l}\text { «Посій насіння з МХП», «Лелека», } \\
\text { «Соціальний магазин», БФ «Урожай } \\
\text { громаді», БФ «Майбутнє для громади», } \\
\text { «Культурна спадщина», «Добробут } \\
\text { громади», «Лідери змін», «Лікар для } \\
\text { села». }\end{array}$ \\
\hline «Астарта» & $\begin{array}{l}\text { - Довкілля; } \\
\text { - біобезпека; } \\
\text { - етична лінія підтримки; } \\
\text { - умови праці; } \\
\text { - турбота про рослин, тварин; } \\
\text { - якість продукції. }\end{array}$ & $\begin{array}{l}\text { «Моє майбутнє Агро», «Гуманна } \\
\text { педагогіка», «ІТ-освіта, «Підйом», «Рід: } \\
\text { розвивайся, інтегруйся, дій», «Чисте } \\
\text { довкілля», «Естафета добра». }\end{array}$ \\
\hline $\begin{array}{l}\text { «Контінентал } \\
\text { фармерз груп» }\end{array}$ & $\begin{array}{l}\text { - Довкілля; } \\
\text { - умови праці; } \\
\text { - турбота про рослин, тварин; } \\
\text { - якість продукції; } \\
\text { - співпраця з громадами. }\end{array}$ & $\begin{array}{l}\text { Адресна допомога, армія, медицина, } \\
\text { освіта, культура, благоустрій. }\end{array}$ \\
\hline
\end{tabular}

Джерело: сформовано автором за матеріалами джерел [6-9] 
- створення багатосторонніх проєктів;

- ранжування напрямів соціальної відповідальності за рівнем актуальності;

- надання податкових пільг, субсидій відповідно до участі суб' єктів господарювання у проведенні соціальної відповідальності бізнесу [13].

Висновки. Таким чином, соціальна відповідальність бізнесу постає як ключовий фактор формування необхідного рівня конкурентоспроможності підприємства, тому українським суб'єктам господарювання важливо розглянути філософію бізнесу 3 урахуванням інтересів стейкхолдерів. Для цього потрібно здійснити низку реформ і трансформацій як у законодавчому полі, так і у суспільному ладі. Однак розпочати варто 3 формування у свідомості громад розуміння змісту, значимості та мети соціально відповідального бізнесу; забезпечення комунікативного центру, який дасть змогу безперервно знаходити напрями та місця реалізації соціальних програм; формування асоціацій, «партнерських» мереж задля підвищення поінформованості представників бізнесу про важливість СВБ; залучення іноземних спеціалістів для обміну досвідом та координації діяльності вітчизняних підприємців. Загалом потрібно вибудувати чітку систему 3 людського, інформаційного та соціального капіталу, що дасть змогу мінімізувати дисперсію заходів соціального характеру, які зовсім не стосуються стійкого розвитку, та водночас максимізувати соціальний ефект від реалізації спільних проєктів і програм. Перспективним постає дослідження українських концептуальних івентів із залученням іноземних спеціалістів на мезо- та макрорівнях.

\section{Список використаних джерел:}

1. Davis K. Understanding the social responsibility puzzle: what does the businessman owe to society. Business Horizons. 1967. № 10(4).

2. Kotler Ph., Lee N. Corporate social responsibility: doing the most good for your company and your cause / translated from English. S. Yarynych. Kyiv : Standard, 2005. 302 p.

3. Porter M., Kramer M. Strategy and Society: The Link between Competitive Advantage and Corporate Social Responsibility. Harvard Business Review. 2006. № 84(12).

4. Акімова І., Марцинків А., Осінкіна О. Соціальна відповідальність бізнесу: розуміння та впровадження. Київ : КІT, 2005.41 с.

5. Воробей В., Журовська I. Соціальна відповідальність бізнесу. Українські реалії та перспективи. URL: www.svb.org.ua (дата звернення: 14.08.2020).

6. Звіт «ACTAPTA». URL: https://astartaholding.com/files/uploads/40e7e7fda11bfec99a3a436f0521a2ff.pdf(дата звернення: 14.08.2020).

7. «Контінентал фармерз груп». URL: https://cfg.com.ua (дата звернення: 14.08.2020).

8. «Миронівський хлібопродукт». URL: https://www.mhp.com.ua/uk/responsibility/communication/nashi-proekti-kso (дата звернення: 14.08.2020).

9. Соціальний звіт «КЕРНЕЛ». URL: https://razom.kernel.ua/kompaniyakernel/sotsialniinitsiativi (дата звернення: 14.08.2020).

10. Корпоративна соціальна відповідальність / за заг. ред. Т. Смовженко, А. Кузнєцової. 2-ге вид., випр. і доп. Київ : УБС НБУ, 2010. 314 с.

11. Мельник С. Становлення соціально орієнтованого бізнесу в Україні як складова державної соціальної політики. Україна: аспекти пращі. 2008. № 5. С. 32-36.

12. Антонюк О. Проблема «невидимой руки» рынка Спільне. URL: https://commons.com.ua/uk/problema-nevidimoj-rukirynka (дата звернення: 14.08.2020).

13. Рамазанов А. Концепція корпоративної соціальної відповідальності. Проблеми теорії та практики управління. 2010. C. $38-46$.

14. Шевчук П. Порівняльна соціальна політика у країнах ЄС : навчальний посібник / за заг. ред. М. Бойцуна, Я. Мудрого, О. Рудіка. Львів : ЛРІДУ НАДУ, 2009. 170 с.

\section{References:}

1. Davis K. Understanding the social responsibility puzzle: what does the businessman owe to society. Business Horizons, 1967, no. 10(4).

2. Kotler, Philip and Lee, Nancy (2005). Korporatyvna sotsialnavidpovidalnist. Yak zrobyty yakomoha bilshe dobra dlia vashoi kompanii ta suspilstva [Corporate social responsibility: doing the most good for your company and your cause]. Translated from English. S. Yarynych. Kyiv: Standard.

3. Porter M., Kramer M. Strategy and Society: The Link between Competitive Advantage and Corporate Social Responsibility. Harvard Business Review, 2006, no. 84(12).

4. Akimova I. Social'na vidpovidal'nist' biznesu: rozuminnya ta vprovadzhennya / I. Akimova, A. Marcinkiv, O. Osinkina. Kyiv: KIT, 2005. $41 \mathrm{~s}$.

5. Vorobej V., Zhurovska I. "Socialna vidpovidalnist biznesu. Ukrayins'ki realiyi ta perspekty'vy". Available at: www.svb.org.ua (accessed 14.08.2020).

6. Zvit "ASTARTA". Available at: https://astartaholding.com/files/uploads/40e7e7fda11bfec99a3a436f0521a2ff.pdf (accessed 14.08.2020).

7. "Kontinental farmerz hrup". Available at: https://cfg.com.ua (accessed 14.08.2020).

8. "Myronivskyi khliboprodukt”. Available at: https://www.mhp.com.ua/uk/responsibility/communication/nashi-proekti-kso (accessed 14.08.2020).

9. Sotsialnyi zvit "KERNEL". Available at: https://razom.kernel.ua/kompaniyakernel/sotsialniinitsiativi (accessed 14.08.2020).

10. Korporatyvna socialna vidpovidalnist (2010) / za zag. red. T. Smovzhenko, A. Kuznyeczovoyi. Vyd. druge, vypravl. i dopovn. Kyiv: UBS NBU.

11. Melnyk S. (2008). Stanovlennya social'no oriyentovanogo biznesu v Ukrayini yak skladova derzhavnoyi social'noyi polity'ky [Establishment of socially preserved business in Ukraine as a component of various social rights]. Ukrayina: aspekty praci, no. 5, pp. 32-36.

12. Antonyuk O. Problema "nevydymoj ruky". Spilne. Available at: https://commons.com.ua/uk/problema-nevidimoj-ruki-rynka

13. Ramazanov A. (2010). Koncepciya korporatyvnoyi social'noyi vidpovidalnosti [The concept of corporate social responsibility]. Problemy teoriyi ta praktyky upravlinnya, pp. 38-46.

14. Shevchuk P. (2009). Porivnyal'na social'na polity'ka u krayinax YeS [Comparative social policy in EU countries]. Lviv: LRIDU NADU. 
Novikov Dmytro

Kyiv National University of Technologies and Design

\section{CONCEPT OF SOCIAL RESPONSIBILITY OF BUSINESS IN THE AGRICULTURAL SECTOR OF UKRAINE}

The purpose of the article is to determine the state of development of CSR of the largest agricultural enterprises of Ukraine and to form appropriate recommendations for solving existing problems. CSR is one of the less priority areas of activity. Therefore, the main task is to build a strategy for the development of the company taking into accounts the principles and postulates of CSR. The basic method of observation, comparing and analysis are used for researching. In the article is considered the theoretical foundations of social responsibility of business, in particular, focused on compliance with the principles of responsible introduction of economic activity in the Ukrainian agricultural sector. Foreign and domestic opinions on the definition of CSR have been studied. The definition of CSR for agricultural enterprises has been created. The general situation of CSR implementation in Ukrainian agriculture is described. Especially, there are presented main features of its using. As a result, a conceptual-modern definition of the notion - "social responsibility of agricultural enterprises" has been formed. For understanding the basic requires of using CSR in Ukraine, the worldwide CSR models are analyzed and their advantages and disadvantages are revealed. The reasons that prevent the transformation of CSR into a strategic component of the enterprise are discovered. The stage of CSR policy formation in Ukrainian agriculture is determined. Based on the method of observation and comparison, the main problems of Ukrainian CSR are identified. The main features of the Ukrainian pseudo - CSR model are determined. On the example of the largest landowners of Ukraine, a comparative description of social policy is conducted, within finances and the number of activities and projects. The main directions of CSR implementation by Ukrainian agrarians are formed. The aims of CSR are presented and given short explanation of its benefits for each entity in business. Recommendations for further development and implementation of CSR models at the appropriate levels of business have been developed. Also new directions of future researching are defined.

Key words: social responsibility of business, social responsibility of agricultural enterprises, CSR models, competitive advantage, landowners of Ukraine, stakeholders.

JEL classification: A13, L24, O13 